\title{
Trauma-Focused Cognitive Behavioral Therapy to reduce symptoms of post-traumatic stress disorder in adolescent victims of incest
}

\author{
Vriska Putri Rakhmasari ${ }^{1}$ Fuad Nashori, ${ }^{1}$ Yudi Kurniawan ${ }^{2 *}$ \\ ${ }^{1}$ Faculty of Psychology and Socio-Cultural Sciences, Universitas Islam Indonesia, Yogyakarta - Indonesia, \\ ${ }^{2}$ Faculty of Psychology, Universitas Semarang, Semarang - Indonesia
}

\begin{abstract}
The threat of sexual violence can occur anywhere, including in the family environment. The subject of this study was a fifteen-year-old girl with a diagnosis of post-traumatic stress disorder who had been a victim of incest by her stepfather. The study aims to examine the effectiveness of trauma-focused cognitive behavioral therapy to reduce symptoms of post-traumatic stress disorder. It uses a Single CaseSingle Subject ABA design. The intervention involved 12 sessions of trauma-focused cognitive-behavioral therapy. Symptoms of posttraumatic stress disorder were measured by the Child Posttraumatic Stress Disorder Symptom Scale (CPSS). There was a change in the CPSS scores in the intervention and post-intervention processes, with the post-traumatic stress disorder scores changing from the moderate to the mild category of post-traumatic stress disorder. The decrease in the scores was also evidenced by the results of the different pre-intervention, intervention, and postintervention CPSS scores using Mann-Whitney nonparametric analysis. The study has implications for the application of trauma-focused cognitive-behavioral therapy to reduce symptoms of post-traumatic stress disorder in adolescent girls who are victims of incest.
\end{abstract}

Keywords: incest; post-traumatic stress disorder; sexual violence; trauma-focused cognitive behavioral therapy

\begin{abstract}
Abstrak: Ancaman kekerasan seksual dapat terjadi di manapun, termasuk di lingkungan keluarga. Subjek dalam penelitian ini adalah perempuan berusia lima belas tahun dengan diagnosis gangguan stres pascatrauma yang menjadi korban inses oleh ayah tiri. Penelitian ini bertujuan menguji efektivitas terapi kognitif perilaku berfokus trauma untuk mengurangi gejala gangguan stres pascatrauma pada subjek. Penelitian ini menggunakan desain Single Case-Single Subject $A-B-A$. Intervensi dalam penelitian ini adalah 12 sesi terapi kognitif perilaku berfokus trauma. Gejala gangguan stres pascatrauma diukur dengan Child Posttraumatic Stress Disorder Symptom Scale (CPSS). Ada perubahan skor CPSS dalam proses intervensi dan pascaintervensi yang menunjukkan skor gangguan stres pascatrauma berubah dari kategori sedang menjadi gangguan stres pascatrauma kategori ringan. Penurunan skor tersebut juga dibuktikan oleh hasil uji beda skor CPSS praintervensi, intervensi, dan pascaintervensi dengan menggunakan analisis nonparametrik MannWhitney. Penelitian ini berimplikasi terhadap aplikasi terapi kognitif perilaku berfokus trauma untuk mengurangi gejala gangguan stres pascatrauma pada remaja perempuan korban inses.
\end{abstract}

Kata Kunci: inses; gangguan stres pascatrauma; kekerasan seksual; terapi kognitif perilaku berfokus trauma

\footnotetext{
*Corresponding Author: Yudi Kurniawan (yudikurniawan@usm.ac.id), Faculty of Psychology, Universitas Semarang, Jl. SoekarnoHatta, Tlogosari Kulon, Semarang 59160-Indonesia.
} 


\section{Introduction}

The Ministry of Women's Empowerment and Child Protection Republic of Indonesia (the Ministry of WECP/ Kementerian Pemberdayaan Perempuan dan Perlindungan Anak Republik Indonesia - PPPA) set the theme "The Role of Families in Child Protection" as an issue raised on the 2019 National Children's Day (Suyanto, 2019). This theme had become important and relevant to be discussed because in recent years there have been indications that the existence of families, especially parents, can be a threat to the safety of children at home. Parents who expected to be the main protectors of child safety can in practice be perpetrators of physical, psychological, and sexual violence against children (Suyanto, 2019).

Based on the National Survey of Life Experiences for Children and Adolescents conducted by the Ministry of WECP in 2018, it was found that three out of five girls and one in two boys had experienced emotional violence. In addition, one in eleven girls and one in 17 boys have experienced sexual violence. The survey results corroborate the reports of cases of sexual violence against children received by the Indonesian Child Protection Commission (ICPC/ Komisi Perlindungan Anak Indonesia - KPAI) between 2011 and 2016. In 2017, the KPAI data recorded 1,965 cases of children who had been victims of sexual violence such as rape, sexual abuse, sodomy, and pedophilia (KPAI, 2017a). Perpetrators of violence are generally close people known to the victims, such as friends at school, teachers, relatives, and parents (SIMFONIPPA, 2021).

One of the regions with the highest reported cases of violence against women and children in
Indonesia is Central Java. From Januari until midFebruary 2020 alone, there had been 43 cases of violence against women and children in Central Java. This figure represented 9.4 percent of the number of cases of violence against women and children nationally (SIMFONI-PPA, 2021). Semarang is the city in Central Java with the most reports of cases of violence against women and children. Throughout 2019, there were 37 reports of sexual violence cases in the city. When disaggregated by age range, the number of child victims (aged 0-18 years) was 91 (DP3A Kota Semarang, 2020).

Referring to the initial assessment conducted by researchers at the Integrated Service Center (Pusat Layanan Terpadu - PPT), cases of violence against women and children in Semarang City, included sexual violence perpetrated against children in the form of forced sexual relations, sexual immorality, and sodomy. According to a psychologist at PPT X Semarang City, in some cases sexual violence was committed by those closest to the victim, in this case the parents. This is in line with the data recorded in the Indonesian Child Protection Commission Data Bank, showing that the majority of perpetrators are people close to, and/or known by, the victims (KPAI, 2017b). Sexual intercourse, whether voluntary or coercive between two people who are related, is a form of incest.

In the National Commission on Violence against Women (Komnas Perempuan) Annual Notes, incest cases are still prevalent in Indonesia. The number of cases recorded in 2016 to 2017 was 1,265; from 2017 to 2018 there were 1,210 cases; from 2018 to 2019 1,071 cases; and 822 cases reported between 2019 and 2020 (Komisi Nasional Anti Kekerasan terhadap Perempuan, n.d.). The number of recorded incest cases has 
therefore decreased from year to year, however Komnas Perempuan emphasizes that the number of recorded cases is reported cases, and it is believed that there are more cases that are not reported, especially as incest is taboo in society.

Incest is a sexual relationship between close relatives who are forbidden by law to marry (Nevid et al., 2018). According to Chaplin (2006), incest is defined as a sexual relationship involving someone of the opposite sex who has very close blood ties. The degree of the relationship is governed by laws and social customs. Incest is an inbreeding relationship between a man and a adolescent girl, either inside or outside a marriage bond, who are related by very close kinship or descent (Kartini, 2009). Benjamin and Sadock (2012) define incest more broadly as sexual relations between subject who have formal or informal blood ties, who are culturally forbidden to have sexual intercourse. Fathers, step fathers, uncles and older siblings committed the most sexual abuse on younger.

The researchers conducted an initial assessment of incest cases received by the Integrated Service Center for the Protection of Women and Children in Semarang City. The incest case chosen for study occurred between a stepfather (the perpetrator) and his 15-year-old daughter (the victim, referred to as AY), who were also the subject in the study. The first assessment was conducted on January 28, 2020 in the counseling room of AY's school counseling teacher's office. AY was a 15-year-old girl; her mother remarried when A was three years old. A lived with her mother and stepfather from the age of three until she was in the fourth grade of elementary school, and then lived with her grandparents until she graduated from elementary school. She returned to live with her mother and stepfather when she was in the seventh grade of Junior High School. Since then, AY experienced sexual violence from her stepfather from June 2017 to December 142019.

The perpetrator, who was AY's stepfather, often committed acts of violence against AY's mother, who experienced dependence on the perpetrator both materially and psychologically. Several times AY heard that the perpetrator had committed acts of violence against her mother. This was what AY considered as not telling what happened to her mother. AY was afraid that if she said her what happened to her mother, the perpetrator would beat her again. The acts of sexual violence experienced by AY were always committed by the perpetrator while AY was sleeping. A fully aware about the actions taken by the perpetrator, but was afraid to fight back, so pretended to be asleep while occasionally shaking off the perpetrator's hand or body, but this did not stop him.

Noviana (2015) reveals that sexual violence against children has a long-lasting impact on their future health and is also related to prolonged trauma in adulthood. Psychologically, it can cause addiction, trauma, and lead to feelings of revenge. Child sexual abuse can cause the victim to experience emotional instability; become quieter; be reluctant to leave the house; suffer depression, fright and anxiety; be prone to daydreaming; feel shy and inferior; dropout; be ostracized by their family; alienate their neighbors; threaten the survival of their family; feel disturbed; experience an absence of clarity on their status as a result of the incest; and children who are born have physical and psychological disorders (Tursilarini, 2017). 
Several studies on sexual violence suggest that sexual violence increases the likelihood of survivors experiencing post-traumatic stress disorder (Fu'ady, 2011). McNew and Abell (1995) compared post-traumatic stress symptoms between Vietnamese war veterans and adult survivors of childhood sexual violence, revealing that sexual violence in childhood produces symptoms comparable to trauma related to the Vietnam war.

Referring to previous studies, the researchers gave the Child PTSD Symptom Scale (CPSS) to the subject (single case, referring to AY). The scale consists of 24 items, each of which is an indicator of post-traumatic stress disorder in children and adolescents. The scale score obtained by the subject was thirty, indicating that she fell into the moderate PTSD score category (hereafter referred to as post-traumatic stress disorder).

The Diagnostic and Statistical Manual of Mental Disorder (fifth edition) defines posttraumatic stress disorder as an anxiety reaction that occurs in individuals who are exposed to threats and situations that can cause death, serious physical injury or disability, or who have faced/witnessed sexual violence. In the DSM-5, there are several criteria and symptoms relating to individuals experiencing post-traumatic stress disorder, including: 1) repeated traumatic events; 2) avoidance; 3) changes in cognition and mood that become negative; and 4) excessive sensory stimulation five stimuli (hyperarousal) (American Psychiatric Association, 2013)

From the results of the assessment conducted by researchers (interviews, observation and the CPSS scale), and based on the Diagnostic and Statistical Manual of Mental Disorder (DSM-5), the symptoms experienced by subject indicated that the subject had posttraumatic stress disorder. Subject experienced repeated traumatic events, including: 1) often having unpleasant thoughts or memories about the traumatic event they experienced; 2) sometimes having difficulty falling asleep or sleeping soundly; 3) sometimes experiencing nightmares; 4) sometimes feeling as if the traumatic event had recurred; 5) always feel uncomfortable when thinking about or listening to the event; 6) when thinking about, hearing or talking about the traumatic event they experienced, often experiencing cold sweat, excessive sweating of the palms of the hands and rapid heart beat.

Subject also practice avoidance, namely: 1) always trying not to feel, talk about or think about traumatic events they have experienced; and 2) often trying to avoid activities, people, or places that remind them of the traumatic event.

Subject experienced several changes in cognition and mood, including: 1) often being unable to remember important parts of the traumatic event they experienced; 2) sometimes losing interest in usual activities; 3) often being unable to feel happy; and 4) feeling negative emotions continuously but not being able to express what kind of emotions they were feeling.

Subject also experienced several symptoms of hyperarousal, namely: 1) often feeling irritable and angry; 2) at least once a week having difficulties sleeping well; 3) finding it very difficult to concentrate on various activities; 4) often overly feeling cautious/vigilant; and 5) sometimes being easily surprised.

In the case of trauma, two main research interventions have been shown to reduce symptoms of post-traumatic stress disorder: Eye Movement Desensitization and Reprocessing 
(EMDR) and trauma-focused cognitive behavioral therapy. A meta-analysis study conducted by Lewey et al. (2018) found evidence that both EMDR and trauma-focused cognitive behavioral therapy were effective intervention methods to reduce post-traumatic stress disorder in children and adolescents. When analyzing variability in the research results, the findings suggest that traumafocused cognitive behavioral therapy is slightly more effective in reducing post-traumatic symptoms in this group. conducted research on groups of adolescent girls who had experienced sexual violence and concluded that traumafocused cognitive behavioral therapy and multidimensional group therapy were effective interventions to reduce symptoms of post-traumatic stress disorder.

Powell et al. (2019) conducted a study entitled Determinants of Implementing EvidenceBased Trauma-Focused Interventions for Children and Youth: A Systematic Review using meta-analysis. The authors conducted a systematic review to identify the determinants for implementing evidence-based psychosocial interventions for children and adolescents experiencing emotional or behavioral difficulties due to trauma exposure. Twenty-three articles were included, all of which examined the implementation of trauma-focused cognitive behavioral therapy in schools. The conclusion of the research was that such therapy can be applied at multi-levels and multi-phases involving related parties, which in the context of this research was the traumatized child.

Trauma-focused cognitive behavioral therapy (TF-CBT) is a component-based psychosocial care model that includes elements of cognitive behavior, attachment, humanism, and empower- ment (Hendricks et al., n.d.). In this therapy, child and adolescent clients are encouraged to develop trauma narratives that gradually tell stories about what happened during their traumatic experience (Lewey et al., 2018), but the therapist can adjust the therapy exposure to focus on emotional expression games or exercises. Research results have shown that such therapy is superior to supportive therapy for children and adolescents who have experienced sexual violence (Lewey et al., 2018).

Based on these previous studies, for this study the researchers chose this type of therapy to overcome the post-traumatic stress disorder experienced by the subject. It was chosen because it has been empirically proven to reduce mental and emotional problems, which are factors that affect such disorder.

\section{Method}

The single case-single subject A-B-A design method was employed (Sunanto et al., 2005). This method is used with repeated measurements before giving a commitment to the subject. It allows subject to control themselves during the treatment. Research using a single-case design aims to explore the behavior of research subject by observing differences in behavior before and after the intervention is given (Furlong et al, 2000).

The dependent variable in this study is posttraumatic stress disorder and the independent variable is trauma-focused cognitive behavioral therapy. Operationally, post-traumatic stress disorder is the score obtained by study subject after filling in the Child Posttraumatic Stress Disorder Symptom Scale (CPSS). Conceptually, post-traumatic stress disorder is a type of 
psychological disorder that belongs to the cluster of anxiety disorders and can be grouped into three main symptoms, namely increased arousal to stimuli related to traumatic events; blunt emotions and avoidance of situations that can lead to trauma; and feelings such as re-experiencing the traumatic event (re-experiencing).

Symptoms of post-traumatic stress disorder in children and adolescents can be measured using the Child Posttraumatic Stress Disorder Symptom Scale (CPSS). This was developed by Foa, Johnson, Feeny, and Treadwell (Foa et al., 2001) and later adapted by the Faculty of Psychology University of Indonesia team in 2013. The scale consists of two parts, consisting of 17 and seven items.
TF-CBT is a component-based model of psychosocial care and intervention that incorporates elements of cognitive behavior, attachment, humanistic, and family empowerment models. It includes several core care components designed to be provided flexibly to meet the unique needs of each child and family. There is strong scientific evidence that this therapy works in treating trauma symptoms in children, adolescents, and their parents. The model was originally developed to address trauma associated with child sexual abuse and was later adapted for use with children who have experienced a variety of traumatic experiences, including trauma associated with sexual abuse (Learning from Research and Clinical Practice Core and Child Sexual Abuse Task Force, 2004).

\section{Table 1}

Steps in Trauma-Focused Cognitive Behavioral Therapy

\begin{tabular}{|c|c|c|}
\hline Encounter & Session & Duration \\
\hline First & $\begin{array}{l}\text { First Session: Building Rapport, Orientation } \\
\text { towards Therapy and TF-CBT, Engagement } \\
\text { Second Session: Psychoeducation and Reaction to } \\
\text { Trauma }\end{array}$ & $45-90$ minutes per session \\
\hline Second & $\begin{array}{l}\text { Third Session: Relaxation } \\
\text { Fourth Session: Recognizing emotions }\end{array}$ & 45 - 90 minutes per session \\
\hline Third & $\begin{array}{l}\text { Fifth Session: Feelings Assessment and } \\
\text { Modulation of Momentary Emotion Expression } \\
\text { Sixth session: Grounding and Mindfullness }\end{array}$ & 45 - 90 minutes per session \\
\hline Fourth & $\begin{array}{l}\text { Seventh Session: Cognitive Process } \\
\text { Eighth Session: Creating Trauma Narratives and } \\
\text { Processing Traumatic Experiences }\end{array}$ & 45 - 90 minutes per session \\
\hline Fifth & $\begin{array}{l}\text { Ninth Session: Managing Trauma with In Vivo } \\
\text { Techniques } \\
\text { Tenth Session: Conjoined Sessions - Sharing } \\
\text { Traumatic Experiences }\end{array}$ & 45 - 90 minutes per session \\
\hline Sixth & $\begin{array}{l}\text { Eleventh Session: Improving and Developing } \\
\text { Safety in the Future } \\
\text { Twelfth Session: Review and Termination }\end{array}$ & 45 - 90 minutes per session \\
\hline
\end{tabular}


The therapist will need time and support to undertake this intensive work. They must also be able to provide interventions that can last 12-25 sessions. While not all children need the full protocol, some components may require more time with multiple clients if they are to be effective. Teaching new skills or changing maladaptive cognitions often requires repeated sessions, as well as practice between sessions. In addition, the trauma narrative component should not be delivered if the setting cannot offer regular sessions or if the children remain in a hazardous environment, as the component is based on the principle that repeated exposure to an upsetting memory gradually reduces negative emotional responses or overcomes maladaptive avoidance. In this study, the intervention lasted for 12 sessions based on the module that was adapted by the researchers.

The subject in this study were adolescent victims of family sexual violence (incest) who were experiencing post-traumatic stress disorder. The researchers determined one particular research subject: 1) AY 15-year-old female adolescent; 2) she had experienced incidents of sexual violence and subsequent symptoms of posttraumatic stress disorder for more than one month, according to the DSM 5 diagnosis criteria; 3) subject are declared to have post-traumatic stress disorder when their score on the Child PTSD Symptom Scale is 30, in the moderate category; 4) subject are willing to be fully involved in this research.

Data collection for the study was made through the interview method, observation, and psychological scales. Post-traumatic stress disorder variables were measured using the Child PTSD Symptoms Scale (CPSS), which consists of two parts; the first includes 17 items and the second seven items. The CPSS was first developed by Foa, Johnson, Feeny, and Treadwell (2001) based on the concept of post-traumatic stress disorder experienced by children and adolescents according to the DSM-4 (Foa et al., 2001). Based on the results of psychometric tests (validity and reliability) on 75 subject aged 8 to 18 years, the alpha coefficient for internal consistency was 0.89 . For validity, after comparison with the Child Post Traumatic Stress Disorder Reaction Index (CPTSD - RI), the CPSS has a product moment correlation coefficient of 0.80 .

Foa, Asnaani, Zang, Capaldi, Yeh (2017) performed psychometric calculations again on the CPSS, which had been adjusted to the posttraumatic stress disorder category on the DSM-5, and an alpha coefficient for internal consistency of 0.87 was obtained. The subject of this study were 64 children aged 8-18 years who were included in the post-traumatic stress disorder category (Foa et al., 2017).

\section{Results}

The results of the first analysis are the analysis visual inspection by describing the total score of the scale and the total score of the aspects of post-traumatic stress disorder as measured by the Child PTSD Symptoms Scale (CPSS) before intervention, during intervention and after intervention, namely re-experience, avoidance, arousal, and negative thoughts and emotions.

From the figures, it can be seen that from the five times measurement of pre-intervention, during intervention and post-intervention, the CPSS scores for AY's pre-intervention were higher than to those at the time of the intervention and post-intervention. The CPSS scores progressively 


\section{Figure 1}

Visual Inspection Analysis of CPSS Scores

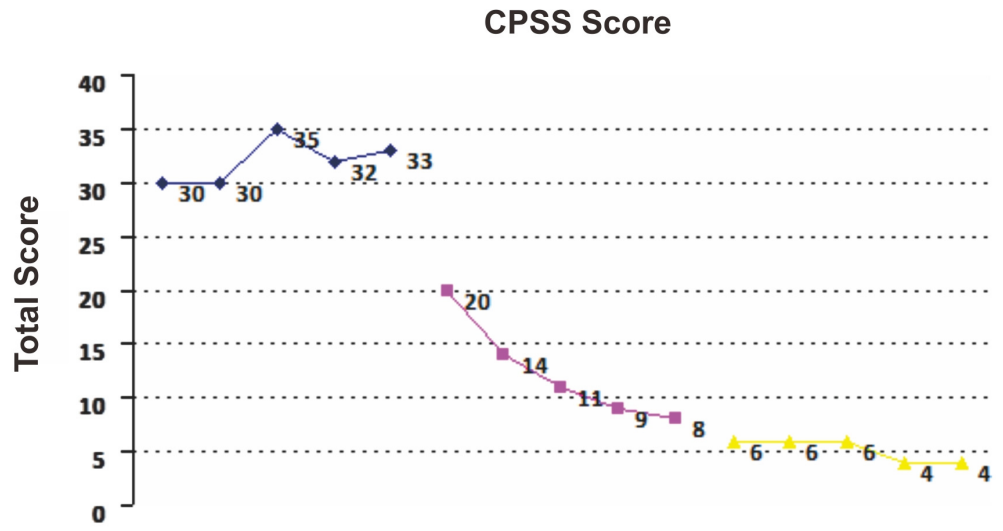

Figure 2

Visual Inspection Analysis of CPSS Scores

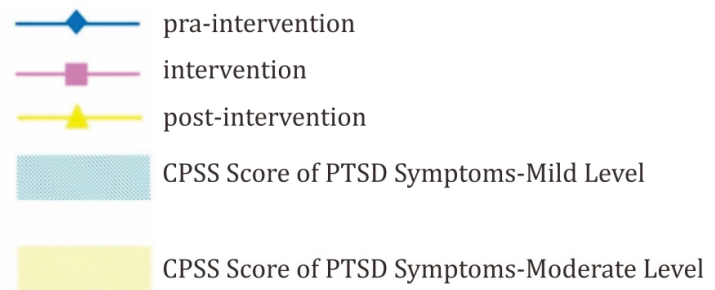

CPSS Score of PTSD Symptoms-Severe Level

decreased with each measurement during the intervention and post-intervention. This suggests that trauma-focused cognitive behavioral therapy was able to reduce the level of post-traumatic stress disorder in AY. The results are proven by A's statement in the follow-up phase, that the skills learned during the therapy process were still being practiced after the intervention process had been completed, meaning that after the therapy was complete (on 20 June 2020) A was able to maintain emotional stability, thoughts and behavior towards stimuli that could trigger traumatic responses.

Based on the results of the analysis with the SPSS program, and the nonparametric MannWhitney difference test, the researchers obtained different test results from the intervention and the post-intervention, with a significant difference of $\mathrm{p}=.008, \mathrm{p}<.01$ (see Table 2). In accordance with these results, the mean CPSS score obtained was 8.80 . 
Table 2

Mann-Whitney Test Result

\begin{tabular}{lc}
\hline & Test Statistics \\
\hline Mann-Whitney U & $<.001$ \\
Wilcoxon W & 15.000 \\
Z & -2.652 \\
Asymp. Sig. (2-tailed) & .008 \\
\hline
\end{tabular}

\section{Discussion}

Based on the results of the research and the data analysis conducted, the researchers found that there was a decrease in post-traumatic stress disorder scores from the moderate to the normal category in subject AY after she had been given the trauma-focused cognitive behavioral therapy intervention. The change in subject AY's scores moved from moderate post-traumatic stress disorder symptoms to the normal category.

The findings of this study support the results of previous research conducted by Goldbeck et al. (2016), who applied trauma-focused cognitive behavioral therapy on subjects aged between 7 and seventeen years in Germany, and showing that the therapy was effective for children and adolescents with post-traumatic stress disorder.

In subject $\mathrm{AY}$, trauma symptoms such as 1) frequent occurrence of unpleasant thoughts or memories about the traumatic event she experienced; 2) difficulties falling asleep or sleeping well and experiencing nightmares; 3) feeling as if the traumatic event had recurred; 4) feeling uncomfortable when thinking about or listening to the event; 5) experiencing cold sweat, excessive sweating on the palms of the hands and a rapid heartbeat when hearing or talking about the traumatic event she had experienced; 6) trying not to feel, talk about or think about the traumatic event she had experienced; 7) trying to avoid activities, people, or places that reminded her of the traumatic event; 8) often being unable to remember important parts of the traumatic event experienced; 9) losing interest in carrying out normal activities; 10 ) unable to really feel happy; 11) feeling negative emotions continuously but not being able to express what kind they were; 12) feeling irritable and getting angry easily; 13) finding it very difficult to concentrate on various activities; 14) being overly cautious/ vigilant; and 15) sometimes being easily startled. After receiving traumatic focused cognitive behavior therapy, the symptoms were no longer felt by subject $A Y$.

Only occasionally do certain symptoms appear, such as 1) thoughts and memories related to the traumatic event; 2) trying not to feel, talk about or think about the traumatic event; 3 ) being unable to remember important parts of the traumatic event; and 4) feeling that she was not close to the people around her. However, for subject AY, the symptoms only appeared occasionally and did not overly bother her.

Research conducted by Hendricks et.al (Hendricks et al., n.d.) explains that cognitive and behavioral therapies are effective for reducing trauma-related symptoms in adults, especially victims of sexual violence (Cohen et al., 2000). There is also substantial evidence that cognitive 
interventions can reduce depressive symptoms (Lewey et al., 2018) and anxiety symptoms. Cognitive distortions can occur as part of children's attempts to understand or explain why a traumatic event occurred. Such thoughts can stem in part from the thoughts children and young people have about what they did in relation to the event, as well as from the process of trying to form meaning out of what happened. The latter component is primarily associated with levels of cognitive development, the capacity for abstract thinking, and perspective taking, and may contribute to older children developing cognitive distortions that are more complex and more disruptive than their impact on younger children (Hendricks et al., n.d.).

Traumatic-focused behavioral cognitive therapy is the most widely used mental health intervention for children and adolescents who have experienced anxiety and trauma disorders (Cary \& McMillen, 2012). It is an intervention technique that focuses on changing thought patterns and fostering adaptive behavior in traumatized individuals (Kiswanto, 2017). Traumatic recovery with this technique is achieved through changing the mindset and behavior affected by the traumatic event. In subject AY, cognitive distortions such as future plans and ideals will not be realized; and the thought that the subject's friends and other people will stay away from her when they know about the traumatic event she experienced; the thought that her mother will be beaten if the subject reports the action of the perpetrator; and the thought that the teachers in AY's school will trust the offender more than the subject could all change after subject AY received trauma-focused cognitive behavioral therapy. Cognitive process sessions with sub-themes of thoughts, feelings and actions; mind diagrams; wrong thoughts; and examination of the evidence, assisted subject AY in changing the cognitive distortions she experienced.

Individuals who have trauma and anxiety tend to have negative and pessimistic thinking patterns, change their mindset to be more optimistic in the sense that they have more hope for their situation, which will help the repair process. The use of trauma-focused cognitive behavioral therapy also needs to consider cultural factors, individual beliefs, and the family values of the clients. In addition, a competent therapist will take into account the possibility of a traumatic event recurring in the therapy session, enabling the client to recover optimally and not experience a relapse (Kiswanto, 2017). This is in accordance with what was experienced by subject AY; after receiving trauma-focused cognitive behavior therapy, she was more able to think and see things from a positive perspective, was better able to control her emotions, and did not take actions based on her fears and concerns related to the traumatic event she experienced.

According to cognitive theory, distorted thinking patterns in traumatic situations can lead to negative emotional states and negative behaviors, including depression, anxiety, symptoms of post-traumatic stress disorder, and selfdestructive or aggressive actions (Cohen et al., 2000). Traumatic-focused cognitive behavioral interventions aim to prevent the development of these adversity difficulties by correcting cognitive errors and enhancing cognitive coping mechanisms (Cohen et al., 2000). After receiving trauma-focused cognitive behavior therapy, subject AY was able to practice skills in grounding and coping, that helped her deal with unwanted situations and thoughts. 
Some limitations related to this study include the adjustment of the CPSS scale to the psychological condition of the subject, who was still emotionally unstable. In addition, the desire of the subject's mother to stop the sexual violence case legal process had an impact on increasing the symptoms of post-traumatic stress disorder in the subject.

\section{Conclusion}

Based on the research, trauma-focused cognitive behavior therapy can be applied and can reduce moderate category symptoms of posttraumatic stress disorder in adolescent victims of incest. The subject felt and experienced positive changes after receiving the therapy. The results are in line with the CPSS score graph, which shows that the subject experienced a decrease in post-traumatic stress disorder scores. This fall occurred in the overall post-traumatic stress disorder scores and also in the scores for the four aspects (those are re-experience, avoidance, arousal, and negative thoughts and emotions) measured by the CPSS scale.]

\section{References}

American Psychiatric Association. (2013). Diagnostic and statistical manual of mental disorder: DSM-5 (5th ed.). American Psychiatric Association.

Benjamin, S., \& Sadock, V. A. (2012). Buku ajar psikiatri klinis. Penerbit Buku Kedokteran EGC.

Cary, C. E., \& McMillen, J. C. (2012). The data behind the dissemination: A systematic review of TraumaFocused Cognitive Behavioral Therapy for use with children and youth. Children and Youth Services Review, 34(4), 748-757. https://doi.org/10.1016/j.childyouth.2012.01.003

Chaplin, J. P. (2006). Kamus lengkap psikologi (K. Kartini (ed.)). Raja Grafindo Persada.

Cohen, J. A., Mannarino, A. P., Berliner, L., \& Deblinger, E. (2000). Trauma-Focused Cognitive Behavioral Therapy for children and adolescents: An empirical update. Journal of Interpersonal Violence, 15(11), 1202-1223. https://doi.org/10.1177/088626000015011007

DP3A Kota Semarang. (2020). Data kekerasan terhadap perempuan \& anak. http://kekerasan.dp3a. semarangkota.go.id/

Foa, E. B., Asnaani, A., Zang, Y., Capaldi, S., \& Yeh, R. (2017). Psychometrics of the Child PTSD Symptom Scale for DSM-5 for trauma-exposed children and adolescents. Journal of Clinical Child \& Adolescent Psychology, 47(1), 38-46. https://doi.org/10.1080/15374416.2017.1350962

Foa, E. B., Johnson, K. M., Feeny, N. C., \& Treadwell, K. R. H. (2001). The child PTSD symptom scale: A preliminary examination of its psychometric properties. Journal of Clinical Child \& Adolescent Psychology, 30(3), 376-384. https://doi.org/10.1207/S15374424JCCP3003_9

Fu'ady, M. A. (2011). Dinamika psikologis kekerasan seksual: Sebuah studi fenomenologi. Psikoislamika: Jurnal Psikologi Dan Psikologi Islam, 8(2), 191-208. https://doi.org/10.18860/psi.v0i0.1553

Furlong, N. E., Lovelace, E. A., \& Lovelace, K. L. (2000). Research methods and statistics an integrated approach (Vol. 2). Horcourt College Pub.

Goldbeck, L., Muche, R., Sachser, C., Tutus, D., \& Rosner, R. (2016). Effectiveness of Trauma-Focused Cognitive Behavioral Therapy for children and adolescents: A randomized controlled trial in eight German Mental Health Clinics. Psychotherapy and Psychosomatics, 85(3), 159-170. https://doi.org/10.1159/000442824 
Hendricks, A., Kliethermes, M., Cohen, J. A., Mannarino, A. P., \& Deblinger, E. (n.d.). Dealing with trauma: A TF-CBT workbook for teens. Trauma-Focused Cognitive Behavioral Therapy - National Therapist Certification Program. https://tfcbt.org/dealing-trauma-workbook-teens/

Kartini, K. (2009). Psikologi abnormal dan abnormalitas seksual. Mandar Maju.

Kiswanto, A. (2017). From helplessness to optimism: Using Trauma Focused-Cognitive Behavioral Therapy (TF-CBT). International Conference on Indonesian Islam, Education and Science.

Komisi Nasional Anti Kekerasan terhadap Perempuan. (n.d.). Menemukenali Kekerasan dalam Rumah Tangga (KDRT).

KPAI. (2017a). Data kasus perlindungan anak berdasarkan lokasi pengaduan dan pemantauan media seIndonesia tahun 2011-2016/ Bank Data Perlindungan Anak Bank Data KPAI 2011-2016. Bankdata.Kpai.Go.Id. https://bankdata.kpai.go.id/tabulasi-data/data-kasus-se-indonesia/datakasus-perlindungan-anak-berdasarkan-lokasi-pengaduan-dan-pemantauan-media-seindonesia-tahun-2011-2016

KPAI. (2017b). Rincian data kasus berdasarkan klaster perlindungan anak, 2011-2016 / Bank Data Perlindungan Anak. Data kasus kekerasan seksual terhadap anak Komisi Perlindungan Anak Indonesia. Bankdata.Kpai.Go.Id.

Learning from Research and Clinical Practice Core and Child Sexual Abuse Task Force. (2004). How to implement trauma-focused cognitive behavioral therapy. National Center for Child Traumatic Stress.

Lewey, J. H., Smith, C. L., Burcham, B., Saunders, N. L., Elfallal, D., \& O’Toole, S. K. (2018). Comparing the effectiveness of EMDR and TF-CBT for children and adolescents: a Meta-analysis. Journal of Child \& Adolescent Trauma, 11(4), 457-472. https://doi.org/10.1007/s40653-018-0212-1

McNew, J. A., \& Abell, N. (1995). Posttraumatic stress symptomatology: Similarities and differences between Vietnam veterans and adult survivors of childhood sexual abuse. Social Work, 40(1), 115-126.

Nevid, J. S., Rathus, S. A., \& Greene, B. (2018). Psikologi abnormal di dunia yang terus berubah (K. Yuniarti, O. M. Dwiasri, \& A. Maulana (eds.)). Erlangga.

Noviana, I. (2015). Kekerasan seksual terhadap anak: Dampak dan penanganannya. Sosio Informa, 1(1). https://doi.org/10.33007/INF.V1I1.87

Powell, B. J., Patel, S. V., Haley, A. D., Haines, E. R., Knocke, K. E., Chandler, S., Katz, C. C., Seifert, H. P., Ake, G., Amaya-Jackson, L., \& Aarons, G. A. (2019). Determinants of implementing evidence-based trauma-focused interventions for children and youth: A systematic review. Administration and Policy in Mental Health and Mental Health Services Research, 47(5), 705-719. https://doi.org/10.1007/S10488-019-01003-3

SIMFONI-PPA. (2021). Peta sebaran jumlah kasus kekerasan menurut provinsi, tahun 2021. Sistem Informasi Online Perlindungan Perempuan dan Anak. https://kekerasan.kemenpppa.go.id/ ringkasan

Sunanto, J., Takeuchi, K., \& Nakata, H. (2005). Pengantar penelitian dengan subjek tunggal. Center for Research on International Cooperation in Educational Development (CRICED) University of Tsukuba.

Suyanto, B. (2019, July 24). Orangtua, pelindung atau ancaman bagi anak. Media Indonesia. https://mediaindonesia.com/opini/248763/orangtua-pelindung-atau-ancaman-bagi-anak

Tursilarini, T. Y. (2017). Dampak kekerasan seksual di ranah domestik terhadap keberlangsungan hidup anak. Media Informasi Penelitian Kesejahteraan Sosial, 41(1), 77-92. https://doi.org/10.31105/mipks.v41i1.2277 
Trauma-Focused Cognitive Behavioral Therapy to reduce .... 